\title{
ARTIKELEN
}

\section{Het rechtsmiddel van verzet is wat waard}

\author{
A. Keuning LLM \& Prof. dr. E. Stamhuis ${ }^{*}$
}

\section{Inleiding}

De wetboeken van strafvordering van Aruba en Curaçao traden in 1997 in werking en hebben - voor een wetboek - nog geen bijzonder hoge leeftijd bereikt. Toch zijn deze codificaties sinds enige jaren voorwerp van heroverweging, waartoe de regeringen een commissie onder voorzitterschap van de procureur-generaal hebben ingesteld, maar welke commissie ook wel de naam draagt van de bekende strafrechtgeleerde H. de Doelder. Deze commissie heeft in haar rapport van eind 2013 blijk gegeven van een brede heroverweging, waarin voor het stelsel van rechtsmiddelen geen grote ingrepen worden voorzien. De commissie adviseerde voor dat specifieke deel van het strafprocesrecht om het hoger beroep en de cassatie in de huidige vorm te behouden en dus aan de praktijk nagenoeg niets te wijzigen. Alleen voor een kleine, vaak genegeerde uithoek van het stelsel werd wel een verandering voorgesteld. Het verzet - een rechtsmiddel dat kan worden ingesteld tegen verstekvonnissen - zou kunnen worden afgeschaft voor misdrijven en alleen voor de vonnissen ten aanzien van overtredingen worden behouden.

$\mathrm{Nu}$ is het genoemde voorstel tot inkrimping een verzachting ten opzichte van de eerste versie van de voorstellen van de commissie. In 2013 werd nog gedacht aan de algehele afschaffing van het verzet, maar dat muteerde in de loop der tijd tot reductie van de scope. Het Arubaanse ontwerp voor de Landsverordening is in het vierde kwart van 2019 aanhangig gemaakt bij de Staten van Aruba. In oktober 2020 is de tekst door het parlement vastgesteld en daarna officieel gepubliceerd in het Afkondigingsblad van Aruba 2020, nr. 163. Tot algehele afschaffing van het verzet lijkt het voorlopig dus nog niet te komen, wel tot een inperking. Maar de inwerkingtreding van deze Landverordening laat nog even op zich wachten en tot die tijd - zo heeft de geschiedenis van de versie 1997 van het wetboek geleerd - is nog van alles mogelijk.

Wij zien in de voorliggende tekst van de Landsverordening aanleiding om de uitkomsten van ons onderzoek naar het rechtsmiddel verzet met de juridisch geinteresseerde Caribische gemeenschap te delen. We staan kritisch tegenover de aangenomen wet en zien tevens aanleiding om een schot voor de boeg te geven. We kunnen immers niet uitsluiten dat op enig moment toch een diepere ingreep in het rechtsmiddel overwogen gaat worden. $\mathrm{Nu}$ de financieel-economische situatie in de landen uiterst penibel geworden is ten gevolge

* A. Keuning LLM is afgestudeerd in het Arubaanse recht (Universiteit van Aruba, 2019) en het International and European Union Law (Erasmus Universiteit Rotterdam, 2020). Dit artikel is mede gebaseerd op haar afstudeerscriptie Arubaans recht. Prof. dr. E. Stamhuis LLM is verbonden aan de Erasmus Universiteit Rotterdam en de Universiteit van Aruba. 
van de COVID-19-crisis, zou een brede zoektocht naar bezuinigingen verwacht kunnen worden waarvan de rechtspraak niet gevrijwaard zal zijn. Dat dan het stelsel van rechtsmiddelen opnieuw gewogen wordt, zou ons niet verrassen. Vermoedelijk is bij weinigen bekend, dat het lot van het rechtsmiddel verzet in Nederland de facto bezegeld werd door een bezuinigingsoperatie. Toen in de crisisjaren voor de Tweede Wereldoorlog in de overheidsfinanciën ingegrepen werd, reduceerde de Bezuinigingswet van 1935 het verzet tot een symbolisch instrument dat vrijwel niet gebruikt kon worden. In 2007 verdween het dan ook uit de wet, zonder dat er een haan naar kraaide. ${ }^{1}$ Welke bezuiniging destijds daadwerkelijk gerealiseerd werd, valt nu moeilijk te achterhalen. Voor de Caribische rechtspleging zal dat overigens evenmin makkelijk te calculeren zijn. Daarvoor is een vrij gedetailleerde collectie van managementdata nodig. Uit het praktijkonderzoek, dat één van de auteurs in het Gerecht in eerste aanleg van Aruba heeft uitgevoerd, is gebleken dat die data niet voorhanden zijn. De jaarverslagen van het Gemeenschappelijk Hof maken ook geen melding van de relevante gegevens. Hoe dat ook zij, wij zullen het financiële argument niet behandelen, maar ons op de juridische merites van het rechtsmiddel verzet concentreren.

Onze bijdrage gaat in zeven onderdelen een aantal punten bespreken die meewegen voor de beantwoording van de vraag of de reductie of zelfs annulering van het verzet in het Wetboek van Strafvordering steun verdient. We geven kort inzicht in de aard van het verzet en de plaats in het stelsel van rechtsmiddelen. Omdat verzet als rechtsmiddel in verstekzaken gepositioneerd is, bespreken we daarna het normatieve kader en de praktijk van de berechting bij verstek. De normen waarover we zullen rapporteren zijn gelijk voor alle landen die het huidige wetboek toepassen, de praktijk is echter alleen in Aruba onderzocht en dus is dat deel van onze bijdrage tot dat land beperkt. Voor de normen volgt eerst de bespreking van het aanwezigheidsrecht, dat voortvloeit uit artikel 6 Europees Verdrag tot bescherming van de rechten van de mens en de fundamentele vrijheden (EVRM). Daarna komt de nationale wettelijke regeling aan de orde, met daarbij de actuele visie van de Hoge Raad op het aanwezigheidsrecht in de nationale strafrechtspleging. In de praktijkrapportage, die daarna aan de beurt is, komen observaties naar voren die zonder een schetsmatige aanduiding van de Nederlandse regeling niet goed begrepen kunnen worden. We zullen dan het praktijkrapport even onderbreken voor een intermezzo. Met deze onderdelen menen wij in het slotdeel een antwoord te kunnen geven op onze onderzoeksvraag, die luidde: 'Wat is de uitkomst van het afwegen van alle juridische argumenten ter zake van de beperking of - wie weet - de afschaffing van het rechtsmiddel verzet?'

1 Wet van 5 oktober 2006, Stb. 2006, 470; i.w.tr. 1 maart 2007. Deze stilte gold niet voor de wetenschap, waar voor reanimatie van het verzet in een nieuwe gedaante nog wel een pleidooi gevoerd was. Zie E.F. Stamhuis, 'Het stelsel van gewone rechtsmiddelen', in: M.S. Groenhuijsen \& G. Knigge (red.), Dwangmiddelen en Rechtsmiddelen. Derde interimrapport onderzoeksproject Strafvordering 2001, Deventer: Kluwer 2002, p. 199-328 en de afwijzing daarvan door de regering in de memorie van toelichting; Kamerstukken II 2005/06, 30320, nr. 3 p. 34-35. In het verslag maakt slechts één fractie nog melding van de afschaffing van de 'antieke en niet vaak gebruikte verzetprocedure' als een goede zaak; Kamerstukken II 2005/06, 30320, nr. 5, p. 6. 


\section{Het rechtsmiddel verzet}

Het nu geldende Wetboek van Strafvordering volgt ten aanzien van het opkomen tegen vonnissen gewezen door het Gerecht in eerste aanleg een dubbelspoor. Tegen zaken waarin de verdachte bij de behandeling aanwezig was, kan de veroordeelde hoger beroep instellen, behalve in het geval hij is vrijgesproken. Maar niet alle zaken worden in aanwezigheid van de verdachte behandeld. Er wordt ook weleens verstek verleend en dan kan de rechter de zaak afdoen zonder de verdachte te hebben gehoord en - in beginsel - zonder weerwoord van de verdediging. Tegen een gewezen verstekvonnis staat namelijk niet het hoger beroep maar het rechtsmiddel verzet open, ook weer indien de verdachte niet is vrijgesproken. Vanzelfsprekend bevat het wetboek een regeling voor de termijnen waarbinnen het rechtsmiddel ingesteld moet zijn. ${ }^{2}$

Een tijdig en op de juiste wijze ingesteld verzet moet leiden tot een nieuwe behandeling van de zaak in alle opzichten. De wet gaat er namelijk van uit wanneer de verdachte bij de nieuwe behandeling van de zaak komt opdagen, dat alle aspecten ter beoordeling voorliggen alsof er niets aan voorafgegaan is; 'als ware het rechtsgeding bij verstek niet voorafgegaan', aldus artikel 433 lid 1 Wetboek van Strafvordering van Aruba (ASv). De rechter moet met inachtneming van het dossier en hetgeen de verdediging aan feiten en verweren aangevoerd heeft, op alle vragen van het strafvorderlijk beslissingsmodel (art. 392 en 394 ASv) een eigen antwoord formuleren. De vergelijking van dat nieuwe antwoord met de inhoud van het verstekvonnis is vervolgens leidend voor hoe de rechter uitvoering geeft aan de opdracht van artikel 433 lid 2 ASv, ten aanzien van het bekrachtigen of vernietigen van dat eerdere vonnis of delen daarvan.

Als de verdachte niet verschijnt bij de nieuwe behandeling, wordt het verzet vervallen verklaard. Na een vervallenverklaring staat de verdachte met lege handen omdat hiertegen geen rechtsmiddel openstaat. De rechter kan de zaak wel een paar keer schorsen om de verdachte de kans te geven te verschijnen, maar dit is niet verplicht. Met het oog op de verenigbaarheid met het straks te bespreken aanwezigheidsrecht van artikel 6 EVRM gelden onzes inziens twee voorwaarden. Allereerst zou het verzet enkel vervallen verklaard mogen worden indien een ondubbelzinnige afstand blijkt, juist omdat het instellen van het rechtsmiddel de wil van de verdachte om aanwezig te zijn doet vermoeden. Ten tweede zou een nieuwe behandeling geboden moeten worden als achteraf een gegronde reden voor afwezigheid bestond. ${ }^{3}$ Maar dan moet er wel een gelegenheid zijn om dat aan de rechter voor te leggen, en die is er nu niet. Vanwege een onhandige keuze door de wetgever in artikel 429 lid 2 ASv kan ook de officier van justitie dit belang van de verdediging niet meer behartigen. ${ }^{4}$ Terzijde zij nog opgemerkt dat extra voorzichtigheid geboden is bij het aannemen van afstand van aanwezigheid in hoger beroep. Noch verzet, noch cassatie staat dan open. ${ }^{5}$

2 Art. 429 lid 1 sub a en b ASv; T.M. Schalken \& S.W. Mul (red.), De nieuwe Antilliaanse en Arubaanse strafvordering, Deventer: Gouda Quint 1998, p. 104 (hierna: Schalken \& Mul)

3 D.V.A. Brouwer, G.A.E. Thodé \& D.H. de Jong, Capita Antilliaans en Arubaans strafprocesrecht, Deventer: Gouda Quint 1998, p. 292 (hierna: Brouwer, Thodé \& De Jong 1998).

4 Brouwer, Thodé \& De Jong 1998, p. 294; in het nieuwe wetboek ongewijzigd; art. 429 lid 2 (nieuw) Sv.

5 Art. 10 lid 2 Rijkswet Cassatieregeling Aruba, Curacao etc. 


\section{Het aanwezigheidsrecht in artikel 6 EVRM}

Het is tijd om te bezien wat artikel 6 EVRM voor Aruba voorschrijft ter zake van verstek en verzet, waarbij we naar de jurisprudentie van het Europees Hof voor de Rechten van de Mens (EHRM) in Straatsburg moeten kijken. Het is consistente rechtspraak, sinds de zaak Colloza ${ }^{6}$, dat het aanwezigheidsrecht moet worden ingelezen in artikel 6 EVRM, omdat aanwezigheid de verdachte in staat stelt effectief gebruik te maken van de rechten die artikel 6 EVRM hem toekent. Het aanwezigheidsrecht is echter niet absoluut, omdat een verdachte daarmee zijn proces zou kunnen stilleggen door opzettelijk weg te blijven of door onvindbaar te zijn. Het recht moet worden afgewogen tegen belangen die de maatschappij heeft bij het afdoen van strafzaken en het berechten van criminelen. ${ }^{7}$ Een verstekprocedure is derhalve onder bepaalde voorwaarden toegestaan.

Allereerst is een berechting in afwezigheid mogelijk indien de verdachte vrijwillig en ondubbelzinnig afstand heeft gedaan van zijn aanwezigheidsrecht. ${ }^{8}$ Voorwaarde is dat de verdachte begrijpt wat deze beslissing voor hem kan betekenen en dat hij op de hoogte is van zijn rechten. ${ }^{9}$ Afstand kan expliciet of impliciet geschieden. Een expliciete afstand verdient de voorkeur, omdat de wil van de verdachte om niet te verschijnen hierbij met de meeste zekerheid is af te leiden. Welk handelen of stilzwijgen van de verdachte voldoende is om een impliciete ondubbelzinnige afstand aan te nemen hangt af van de concrete omstandigheden. ${ }^{10}$ Bovendien is de geldige afstand afhankelijk van de daarmee samenhangende inspanningsverplichting van de autoriteiten om de verdachte tijdig, in een begrijpelijk taal in te lichten over de tijd, plaats en zittingsdatum van de strafzaak. ${ }^{11}$ De verdachte moet daarbij worden ingelicht over zijn rechten, de mogelijkheid om hiervan afstand te doen en de gevolgen daarvan, zodat hij daadwerkelijk in staat wordt gesteld een weloverwogen keuze te maken om te verschijnen of niet. ${ }^{12}$ De informatieverschaffing geschiedt bij voorkeur in persoon. Indien de verdachte vervolgens niet verschijnt, is het stilzwijgen over het algemeen voldoende om afstand aan te nemen. ${ }^{13}$

Indien een dagvaarding niet in persoon is betekend, is meer terughoudendheid geboden bij het aannemen van afstand. De eisen voor de afstand zijn ook afhankelijk van de zwaarte van de straf die voor het delict staat. ${ }^{14}$ Naarmate de strafbedreiging forser wordt, nemen de eisen voor afstand toe en wordt de inspanningsverplichting van de justitiële autoriteiten om de verdachte op de hoogte te brengen groter. Bij lichtere delicten wordt meer verantwoordelijkheid van de verdachte verwacht om bereikbaar te zijn. Dit geldt in het bijzonder als een verdachte een vervolging heeft kunnen voorzien, bijvoorbeeld door een eerder 
gedaan transactievoorstel. ${ }^{15}$ Een verstekberechting zonder ondubbelzinnige afstand kan toch gerechtvaardigd zijn indien de verdachte een nieuwe behandeling van de zaak wordt geboden; aangeduid met de term 'fresh determination'. De nieuwe behandeling moet zowel een nieuw onderzoek naar de feiten als het recht behelzen. ${ }^{16}$ Dit rechtsmiddel moet in de wet gewaarborgd zijn, de verdachte voldoende tijd bieden er gebruik van te maken en neutraal staan tegenover de reden van afwezigheid bij de voorgaande behandeling. ${ }^{17}$ Bovendien mogen er niet te zware toelatingseisen gelden, omdat dit het effectieve gebruik van het rechtsmiddel doorkruist. ${ }^{18}$ De mogelijkheid om effectief gebruik te maken van het rechtsmiddel hangt thans samen met de wetenschap van de verdachte met het verstekvonnis en het recht op de nieuwe behandeling. Indien de nieuwe behandeling de laatste feitelijke instantie voor de verdachte is, dan lijkt een persoonlijke betekening vereist. Wanneer de verdachte in geen van de feitelijke instanties persoonlijk op de hoogte is gebracht van de strafzaak, dan zou hem alsnog een nieuwe behandeling moeten worden geboden na de laatste feitelijke instantie. ${ }^{19}$

Een aanvullende eis die het EHRM aan de verstekberechting stelt, is dat de verdachte zich in afwezigheid mag laten verdedigen door een raadsman. ${ }^{20}$ Deze eis maakte in de Lala- en Pelladoah-zaken een einde aan de klemmende-reden-jurisprudentie van de Hoge Raad, die de verdediging van een raadsman bij verstek uitsloot. Volgens het EHRM mag het rechtsbijstandsrecht niet afhankelijk worden gemaakt van 'formalistic conditions', omdat dit afbreuk doet aan de effectiviteit van het verdedigingsrecht. ${ }^{21}$ De rechter dient een raadsman derhalve direct toe te laten indien het duidelijk is dat hij voor de verdachte optreedt. Hij mag geen nadere toelatingsvoorwaarden eisen.

Ten slotte kan het aanwezigheidsrecht van de verdachte van de rechter vergen dat de strafzaak wordt aangehouden. Allereerst geldt dit voor situaties waarin sterke twijfel bestaat omtrent de afstand van de verdachte, omdat hij bijvoorbeeld niet op de hoogte is gebracht van de zaak en evenmin iets van zich heeft laten horen of dat hij gedetineerd is in het buitenland. ${ }^{22}$

Daarnaast kan de verdachte zelf of zijn raadsman een aanhoudingsverzoek indienen. Een rechter dient altijd gemotiveerd te beslissen op een dergelijk verzoek en daarbij een belangenafweging te maken tussen de voortgang van de strafzaak en de verdedigingsbelangen van de verdachte. ${ }^{23}$ Belangrijk is dat de hiervoor genoemde voorwaarden niet star

15 EHRM 16 december 1992, 12129/86, par. 26-27 (Hennings/Duitsland).

16 EHRM 23 november 1993, 14032/88, par. 31 (Poitrimol/Frankrijk).

17 H.M.E. Lameris-Tebbenhoff Rijnenberg, Dagvaarding en berechting in aanwezigheid: de Nederlandse betekeningsregeling in rechtshistorisch en Europees perspectief (diss. Groningen), 1998, p. 23 (hierna: Lameris-Tebbenhoff Rijnenberg 1998).

18 EHRM 23 november 1993, 14032/88, par. 35 (Poitrimol/Frankrijk).

19 C.F Rütter, annotatie bij EHRM 12 februari 1985, 9024/80, AA 1986, p. 309-315 (Colozza/Italië).

20 EHRM 22 september 1994, 16737/90, par. 40 (Pelladoah/Nederland); EHRM 22 september 1994, 14861/89, par. 33 (Lala/Nederland).

21 EHRM 22 september 1994, 14861/89, par. 34 (Lala/Nederland).

22 EHRM 28 augustus 1991, 12151/86 (F.C.B./Italië).

23 EHRM 14 februari 2017, 30749/12 (Hokkeling/Nederland); J.W. Ouwerkerk, 'Het aanwezigheidsrecht in strafzaken', AA 2017/12, afl. 12, p. 1002. 
zijn en tezamen in het licht van de omstandigheden van het gehele proces moeten worden bezien. Daarmee kan een verstekberechting toch legitiem zijn indien deze niet geheel voldoet aan de hiervoor genoemde vereisten. ${ }^{24}$

\section{De verstekprocedure in de wet en de rechtspraak van de Hoge Raad}

De verstekprocedure blijkt in het wetboek vrij beknopt geregeld te zijn, waarbij veel verantwoordelijkheid bij de rechter wordt gelegd om het aanwezigheidsbelang van de verdachte en het belang van de voortgang en afdoening van de zaak in balans te houden. Dit uit zich in de bevoegdheden zaken aan te houden, medebrenging te gelasten of om verstek te verlenen, die steeds een zelfstandige afweging vereisen. Als een verdachte niet verschijnt, kan de rechter verstek verlenen onder de voorwaarden dat de dagvaarding rechtsgeldig is betekend en de verdachte afstand heeft gedaan van zijn aanwezigheidsrecht. ${ }^{25}$ Rechtsgeldige betekening staat niet gelijk aan 'betekening in persoon', nu de wet ook andere varianten van een geldige betekening beschreven heeft. ${ }^{26}$

Nietigheid van de dagvaarding volgt wanneer de uitreiking niet in overeenstemming geschiedt met de hiervoor genoemde betekeningswijzen. ${ }^{27}$ Als de dagvaarding de wettelijke uitreikingstermijn heeft overschreden, volgt eveneens nietigheid. ${ }^{28}$ Beide nietigheidssancties worden gedekt door verschijning van de verdachte.

Wanneer de dagvaarding geldig is, maar de verdachte niet is verschenen, dient de rechter te toetsen of de verdachte afstand heeft gedaan van zijn aanwezigheidsrecht. De wet biedt hiervoor geen toetsingskader. Houvast kan worden gezocht bij de algemene jurisprudentielijn van de Hoge Raad. Een stilzwijgende afstand mag worden aangenomen als de dagvaarding rechtsgeldig is betekend en de verdachte verschijnt niet, behoudens duidelijke contra-indicaties van deze afstand. ${ }^{29}$ Aanwijzingen die het aannemen van afstand hinderen zijn bijvoorbeeld situaties waarin de verdachte elders gedetineerd is of een buitenlands adres heeft en vermoed kan worden dat de autoriteiten in het betrokken land hoogstwaarschijnlijk geen uitvoering hebben gegeven aan de betekening. ${ }^{30}$ Desalniettemin accepteert de Hoge Raad ook voortgang van zaken indien rechtsgeldig is betekend en het woonadres van de verdachte onbekend is gebleven. Persoonlijke betekening is dus geen vereiste, terwijl in het laatstgenoemde geval moeilijk van afstand gesproken kan worden. ${ }^{31}$

Art. 307 ASv.

Art. 643-645 ASv; Schalken \& Mul 1997, p. 115.

Art. 647 lid 1 jo. 2 ASv.

Art. 290 lid 1jo. 3 ASv.

HR 12 maart 2002, ECLI:NL:HR:2002:AD5163, r.o. 3.33, NJ 2002/317, m.nt. Schalken.

HR 8 februari 2005, HYPERLINK https://www.navigator.nl/document/id34200502080062604admusp? anchor=id-41f3e35d-c8c4-4ed5-af8b-7bdb3b614b96 ECLI:NL:HR:2005:AR8428, NJ 2005/229; HR 15 januari 2002, ECLI:NL:HR:2002:AD8129.

31 In lijn met Kamerstukken II 1994/95, 24692, nr. 3, p. 9 en 11. 
Indien de rechter twijfelt aan de afstand of hij aanwezigheid van de verdachte wenselijk acht, kan hij de zaak schorsen. ${ }^{32}$ Ook mag de verdachte zelf of zijn raadsman een aanhoudingsverzoek indienen. De wet formuleert wederom geen nadere eisen voor deze schorsingsbevoegdheid. In een betrekkelijk recent overzichtsarrest heeft de Hoge Raad uiteengezet hoe aanhoudingsverzoeken behandeld dienen te worden en daarbij blijk ervan gegeven dat het aanwezigheidsrecht serieus genomen moet worden. ${ }^{33}$ Allereerst moet het aanhoudingsverzoek zelf redelijk zijn en een gegronde reden voor afwezigheid aandragen, zoals ziekte of een plotseling overlijden van een naaste. Het verzoek moet met bewijsstukken aannemelijk worden gemaakt. Een onaannemelijk verzoek mag zonder belangenafweging worden afgewezen. ${ }^{34}$ Wordt het verzoek aannemelijk geacht, dan dient een belangenafweging tussen de voortgang van de zaak en het aanwezigheidsbelang gemaakt te worden. Een afwijzing moet vervolgens met redenen worden omkleed. ${ }^{35}$ Naast de schorsingsbevoegdheid, heeft de rechter de bevoegdheid medebrenging te gelasten indien hij aanwezigheid wenselijk acht voor het onderzoek van de feiten en/of de persoonlijke omstandigheden. ${ }^{36}$

Op het punt van de verdedigingsmogelijkheid door een raadsman in afwezigheid van de verdachte is het huidige Caribische wetboek niet bij de tijd. Artikel 306 ASv - geen verstek in geval van een bijzondere volmacht - is een echo uit een ver verleden waarin verstekberechting anders dan nu beperkt was tot overtredingen of misdrijven die niet bedreigd worden met een gevangenisstraf. Volgens het EHRM heeft de verdachte in alle typen zaken recht op verdediging door een raadsman in zijn afwezigheid. ${ }^{37}$ In de Nederlandse wet is dat geregeld in artikel 278 en 279 NLSv, waar bij verdediging door een raadsman de behandeling als op tegenspraak wordt gerubriceerd. Dit recht is echter nog nergens terug te vinden in de Arubaanse wet. De volmachtsbepaling wekt juist de indruk, dat een afwezige verdachte enkel recht heeft op rechtsbijstand in de gevallen die artikel $306 \mathrm{ASv}$ opsomt. De mate waarin de praktijk daadwerkelijk zo restrictief is, bepaalt uiteindelijk of de bestaande rechtspleging zich verdraagt met het hier beschreven recht. Op de impressies uit het praktijkonderzoek gaan we nu in.

\section{De verstekpraktijk in Aruba}

De verstekpraktijk in Aruba is in kaart gebracht door een verkennend veldonderzoek in de periode april-juni 2019. Hiervoor is onderzoek gedaan naar stafdossiers van verstek- en verzetzaken en een verzetregister over een periode van vijf jaar. ${ }^{38}$ Daarnaast zijn interviews afgenomen. Het merendeel van de resultaten is gebaseerd op interviews met leden van het

32 Art. 313 lid 3 ASv.

33 HR 16 oktober 2018, ECLI:NL:HR:2018:1934, NJB 2018/2010, m.nt. Van Oort; o.m. bevestigd in HR 19 mei 2020, ECLI:NL:HR:2020:902.

34 HR 23 januari 2018, ECLI:NL:HR:2018:65, r.o. 2.4, NJ 2018/324, m.nt. Kooijmans.

35 HR 16 oktober 2018, ECLI:NL:HR:2018:1934, r.o. 2.5, NJB 2018/2010, m.nt. Van Oort.

36 Schalken \& Mul 1997, p. 91 en 248.

37 EHRM 23 november 1993, 14032/88, par. 31 (Poitrimol/Frankrijk); EHRM 22 september 1994, 14861/89 (Lala/ Nederland); EHRM 22 september 1994, 16737/90 (Pelladoah/Nederland).

38 Over de periode van 2014 tot en met 2018. 
Gerecht, het openbaar ministerie (OM) en de balie, aangezien de andere onderzoeksmethoden slechts in beperkte mate gegevens konden genereren. De praktijk zal zoveel mogelijk de loop van een strafzaak volgen.

De procedure vangt aan met de betekening van de dagvaarding aan de verdachte. Dit geschiedt door gerechtsdeurwaarders in dienst van het OM. Het uitgangspunt is om zowel gedetineerde verdachten als verdachten op vrije voeten persoonlijk te dagvaarden. Verdachten in Aruba verblijven gemiddeld sneller en langer in hechtenis dan in Nederland. Het OM streeft ernaar deze categorie zoveel mogelijk tijdens het verblijf in voorlopige hechtenis te dagvaarden. Gedetineerden in het Korrektie Instituut Aruba (KIA) worden daar ter plaatse gedagvaard. Bij de verdachten op vrije voeten controleert de gerechtsdeurwaarder eerst het CENSO-adres van de verdachte. Daarnaast wordt ook bekeken of het proces-verbaal van de politie een afwijkend adres bevat. Het CENSO-adres is in beperkte mate betrouwbaar, omdat verhuizingen vaak niet worden doorgegeven. Daarom wordt van het meest recent opgegeven adres uitgegaan. Vervolgens zal de gerechtsdeurwaarder de dagvaarding persoonlijk aan de verdachte uitreiken. Wordt de verdachte niet aangetroffen en klopt het adres, dan wordt de dagvaarding aan een huisgenoot uitgereikt indien zijn CENSO-adres bevestigt dat deze persoon daadwerkelijk ingeschreven staat op het adres. Indien de verdachte niet op het meest recente adres woonachtig is, probeert de deurwaarder via de nieuwe bewoners of buren het nieuwe adres van de verdachte te achterhalen. Vaak is deze methode succesvol, omdat de nieuwe bewoners geregeld bekenden of familie zijn van de verdachte. Als de verdachte niet wordt getraceerd, zal de gerechtsdeurwaarder de dagvaarding achterlaten op het bekende CENSO-adres en eventueel ook op het adres dat uit het proces-verbaal is gebleken. Daarna wordt deze aan de officier van justitie uitgereikt.

Verdachten die in het buitenland wonen worden zoveel mogelijk gedagvaard voordat zij het land verlaten om betekeningsproblemen te voorkomen. Verdachten binnen het Koninkrijk zijn relatief gemakkelijk te dagvaarden, omdat de rechtshulp daar interregionaal van aard is. Voor de overige gevallen zal een internationaal rechtshulpverzoek ingediend moeten worden en ligt de geslaagde betekening in handen van de autoriteiten van deze landen. Buitenlanders die verdacht worden van geringe feiten worden vanuit proceseconomisch oogpunt meestal niet gedagvaard omdat het merendeel niet verschijnt en de executie van de vonnissen nauwelijks realiseerbaar is. Ten slotte is er een categorie verdachten waarvan geen bekend woonadres bestaat. Een deel van deze verdachten betreft de dakloze bevolkingsgroep, de zogeheten 'chollers'. Een groot deel van de chollers is bekend bij de gerechtsdeurwaarders. Dankzij het persoonlijke contact is het toch goed mogelijk de locatie van de meeste chollers te achterhalen en de dagvaarding in persoon uit te reiken.

De informatieverstrekking van de dagvaarding zelf is zeer summier. Deze geeft geenszins informatie over het aanwezigheidsrecht, de gevolgen van afstand of de verdedigingsrechten van de verdachte. Daarnaast wordt de dagvaarding enkel in het Nederlands opgemaakt, terwijl een aanzienlijk deel van de verdachten deze taal niet of nauwelijks beheerst. De gerechtsdeurwaarder licht bij de betekening enkel de inhoud van het feit toe, maar niet de rechten die de verdachte heeft. Ten slotte hebben zowel het OM als de rechters de indruk 
dat een groot deel van de verdachten in Aruba in persoon worden betekend. Betekeningsfouten komen niet vaak voor. De onderzochte strafdossiers onderschrijven dit beeld.

Als de verdachte vervolgens niet verschijnt ter zitting, wordt voor de afstand van het aanwezigheidsrecht onderscheid gemaakt tussen gedetineerden in Aruba en verdachten op vrije voeten. Indien een gedetineerde niet wenst te verschijnen, moet hij een afstandsverklaringsformulier ondertekenen. Verdachten op vrije voeten doen in de praktijk bijna nooit uitdrukkelijk een afstandsverklaring. In principe wordt in die gevallen afstand aangenomen indien de verdachte op behoorlijke wijze is opgeroepen en niet is verschenen. Een van de rechters gaf aan hier nooit uitzonderingen op te maken. De andere rechters houden zaken wel aan indien er sterke twijfel bestaat omtrent de bekendheid van de verdachte met de zitting of over de mogelijkheid te kunnen verschijnen. Verder is de ambtshalve aanhoudingspraktijk onderling niet formeel afgestemd en ziet deze er per rechter verschillend uit.

Voor de behandeling van aanhoudingsverzoeken van de verdediging is geen aanhoudingenprotocol naar de balie gecommuniceerd. Volgens de rechters is het aanhoudingsbeleid soepel en worden alle eerste aanhoudingsverzoeken gehonoreerd, mits het verzoek een goede reden met onderbouwing bevat. Verzoeken worden pas afgewezen indien een strafzaak een aantal keer is aangehouden en de rechter vermoedt dat de verdachte zijn proces poogt stil te leggen. Het OM heeft dit beeld bevestigd. Volgens de rechters worden er relatief weinig aanhoudingsverzoeken gedaan. De leden van de balie stellen dat de aanhoudingspraktijk echter geenszins soepel is. Verzoeken zouden enkel worden geaccepteerd indien een verdachte aantoonbaar ziek is of als het proces-verbaal de verdediging te laat heeft bereikt. Wellicht is dit afwijkende perspectief deels te wijten aan het feit dat de aanhoudingspraktijk niet gestroomlijnd is, waardoor de praktijk door de jaren heen wisselend is geweest. Voorgaande rechters die niet langer werkzaam zijn bij de sectie strafrecht van het Gerecht in eerste aanleg kunnen de aanhoudingspraktijk zodanig hebben beïnvloed, dat de balie hoge eisen voor aanhoudingsverzoeken verwacht en enkel binnen die strikte normen verzoeken indient. Dit zou ook een mogelijke verklaring kunnen geven voor het lage aantal aanhoudingsverzoeken.

Aangezien het Gerecht geen verstekregistratie bijhoudt, is het aandeel verstekzaken van het totaalaantal strafzaken niet bepaalbaar. De respondenten hebben de indruk dat verstek met name voorkomt bij de relatief lichtere strafzaken. Dit is deels verklaarbaar doordat verdachten voor zware feiten over het algemeen gedetineerd zijn, waardoor hun aanwezigheid verzekerd is. Volgens de respondenten verschijnt in het merendeel van de verstekzaken een raadsman. Verschijnt er geen raadsman, dan loopt de kale verstekprocedure voorspoedig doordat de officier van justitie en de rechter het dossier beiden inhoudelijk goed kennen. Bij de zaken waar een raadsman verschijnt, wordt de Lala- en Pelladoah-jurisprudentie gevolgd en krijgt de raadsman zonder nadere eisen het woord ter verdediging. In het verleden bestond er onenigheid over de eisen waaraan de raadsman diende te voldoen. Sommige rechters eisten een machtiging met uiteenlopende bewijscriteria daarvoor, terwijl dit niet voorgeschreven staat in de Arubaanse wet. Momenteel is kortgesloten dat er geen schriftelijke machtiging geëist mag worden. 
Deze afspraak is niet openbaar gemaakt of gecommuniceerd naar de balie. De aanwezigheid van een raadsman heeft geen gevolgen voor de kwalificatie van het strafvonnis als verstekvonnis. Daardoor bestaat er geen wettelijke responsieplicht op de verweren die worden aangevoerd. Een rechter mag daarmee elk verweer naast zich neerleggen zonder enige redengeving. In de praktijk lijkt dit voor weinig problemen te zorgen aangezien rechters serieus om lijken te gaan met de verweren en deze hetzelfde behandelen als verweren bij zaken op tegenspraak.

In principe worden verstekvonnissen hetzelfde betekend als de dagvaarding en staat een persoonlijke betekening voorop. Indien dit onmogelijk is, wordt een mededeling van het vonnis op het bekende adres van de verdachte achtergelaten. Bij een ontbrekend bekend adres volgt aanplakking van de mededeling aan het gerechtsgebouw. Weet het OM een verdachte niet te traceren, dan kan het vonnis niet ten uitvoer worden gelegd, omdat de verzettermijn pas gaat lopen na een omstandigheid waaruit bekendwording met het vonnis blijkt. Voor veroordeelden woonachtig in het buitenland dient voor de executie wederom een internationaal rechtshulpverzoek ingediend te worden, tenzij de veroordeelde binnen het Koninkrijk woont. Bij lichtere feiten wordt het verstekvonnis meestal niet betekend, omdat bekend is dat de executie van dit type vonnis moeilijk haalbaar is. Meldt de verdachte zich bij de Arubaanse grens, dan wordt het vonnis alsnog betekend. De kennisgeving van de veroordeling bevat een mededeling dat de verdachte binnen veertien dagen verzet kan instellen.

Uit het verzetregister dat het Gerecht in eerste aanleg bijhoudt, is gebleken dat het gebruik van verzet over de onderzoeksperiode gering is, zonder dat de proportie te bepalen is. Over het vijftal jaren werd verzet 129 keer aangewend. Opvallend is dat 81\% van deze zaken niet door het OM ter zitting is aangebracht. Enkel zaken die niet enkel overtredingen betroffen, dus alleen misdrijfzaken, zijn aangebracht. Het OM kon niet een precieze reden voor deze gang van zaken aanwijzen. Een mogelijke reden is dat de procedure van binnengekomen verzetten binnen de organisatie van het OM niet is kortgesloten. Het lijkt erop dat het administratiepersoneel niet goed op de hoogte is wat er met het rechtsmiddel dient te gebeuren. Daarnaast zouden proceseconomische redenen meespelen, waarbij het belang van de executie van oudere, lichtere zaken niet opweegt tegen de middelen die gemoeid zijn met het starten van een nieuw proces.

In het leeuwendeel van de aangebrachte verstekzaken werd nauwelijks inhoudelijk afgeweken van het verstekvonnis. In een van de bestudeerde zaken volgde echter wel een aanzienlijke afwijking. De verdachte werd bij verzet vrijgesproken, terwijl deze bij verstek tot achttien maanden celstraf was veroordeeld. Het overige deel van de aangebrachte zaken werd vervallen verklaard, omdat de verdachte niet was verschenen. In de praktijk worden deze zaken waar verzet is ingesteld maar de verdachte niet verschijnt, niet aangehouden om de verdachte nog een kans te bieden. Bij de akte van oproeping wordt de verdachte wel gewaarschuwd voor de vervallenverklaring. 


\section{De gewijzigde verstekregeling}

In het nieuw vastgestelde Wetboek van Strafvordering gaat niet de hele verstekprocedure op de schop. Slechts een aantal punten wordt gewijzigd. Allereerst wordt korte metten gemaakt met een van de nietigheidssancties voor een geldige betekening van de dagvaarding. In het vervolg zal een zaak waarvan de dagvaarding niet binnen de wettelijke termijn is betekend in de regel moeten worden geschorst door de rechter. ${ }^{39}$ Voor de betekening zelf geldt dat deze inhoudelijk nagenoeg hetzelfde blijft. Bepaalde betekeningstermijnen voor verdachten in het buitenland worden verlengd. ${ }^{40}$

Verder verandert er weinig aan de bevoegdheden die de rechter heeft als het aankomt op de verstekverlening, medebrenging en schorsing van de zaak. Wel sluit de nieuwe regeling beter aan op de EHRM-jurisprudentie op het punt van de verdediging door een raadsman. In de wet is nu expliciet vermeld dat een raadsman die zich gemachtigd verklaart zonder nadere eisen de verdediging in afwezigheid van de verdachte mag voeren. ${ }^{41}$ In de praktijk gebeurde dit dus al. Voordeel is dat de wetgever nu duidelijk heeft gemaakt dat een mondelinge machtiging volstaat; een punt waarover in het verleden discussie bestond bij het Gerecht. De wetswijziging wordt echter niet gegrond op een tegemoetkoming van de verdachte in zijn verdedigingsrechten, maar op een versnelling van de procesgang. Indien een raadsman verschijnt verloopt de zaak namelijk op tegenspraak, waardoor het vonnis makkelijker ten uitvoer kan worden gelegd. ${ }^{42}$ Opvallend is dat de wetgever ook de oude volmachtsbepaling voor overtredingen behoudt. De gedachte is dat dit kosten kan besparen voor de verdachte. In deze gevallen is ook sprake van een zaak op tegenspraak. ${ }^{43}$

Voor het rechtsmiddel verzet geldt dat deze als afgeslankte variant blijft bestaan. ${ }^{44}$ Volgens de wetgever hoeft het rechtsmiddel enkel behouden te worden voor de overtredingszaken, omdat verzet in de praktijk nauwelijks voor misdrijven wordt gebruikt en het hoger beroep aan geen enkele barrière is onderworpen. Daarnaast zou verzet nogal eens leiden tot verwarring. Dan wendde de verdachte bijvoorbeeld hoger beroep aan in plaats van verzet, waarna conversie moest plaatsvinden. Uit het praktijkonderzoek is dit voor Aruba niet duidelijk naar voren gekomen. Voor overtredingen lijkt het de wetgever wenselijk om het rechtsmiddel te behouden, om een tijdbelasting van de hof-combinatie te voorkomen. ${ }^{45}$ Kennelijk speelt dit verwarringsargument geen rol voor de overtredingen, terwijl het daarbij juist om meer zaken gaat. Bovendien lijkt de nieuwe regeling alleen nog maar ver-

39 Memorie van toelichting houdende de vaststelling van een nieuwe tekst van het Wetboek van Strafvordering, p. 147; art. 290 jo. 647 nieuw ASv.

40 Zo zal voor de verdachten buiten Aruba maar binnen het Koninkrijk een termijn van veertien dagen komen te gelden en voor verdachten buiten het Koninkrijk een termijn van zes weken, (art. 643 nieuw ASv). MvT houdende de vaststelling van een nieuwe tekst van het Wetboek van Strafvordering, p. 212-213.

41 Art. 306 nieuw ASv.

42 Dit omdat de termijn voor onherroepelijkheid van het vonnis dan direct na de dag van de zitting begint te lopen. Bij verstek gaat deze pas lopen op het moment dat de verdachte bekend is geworden met de uitspraak indien de dagvaarding niet in persoon is betekend (art. 429 jo. $437 \mathrm{ASv}$ ).

43 MvT houdende de vaststelling van een nieuwe tekst van het Wetboek van Strafvordering, p. 152.

44 Art. 429-433 nieuw ASv.

45 MvT houdende de vaststelling van een nieuwe tekst van het Wetboek van Strafvordering, p. 172-173. 
warrender te worden, doordat de verdachte die bij verstek is berecht voor verschillende typen delicten verschillende rechtsmiddelen moet aanwenden.

Los van deze niet zeer overtuigende argumenten voor inkrimping geeft het voorstel blijk van een irreëel beeld van wat er momenteel in de praktijk gebeurt. In werkelijkheid worden enkel de verzetten in misdrijfzaken ter zitting aangebracht en behandeld, terwijl overtredingen op de plank blijven liggen en niet meer ten uitvoer worden gelegd. Zolang dit niet verandert heeft de wetgever dus in feite het ingestelde verzet onbedoeld tot middel gemaakt om een verstekvonnis de facto in de prullenbak te laten belanden. Dat komt het gezag van het rechterlijk vonnis in overtredingszaken niet ten goede.

Bovendien zou juist in misdrijfzaken - waarin de werklast niet bijzonder groot lijkt te zijn - de hernieuwde beoordeling in tegenwoordigheid van de verdediging in de zaak een waardevolle component kunnen zijn van de rechtspositie van de verdachte. Nota bene, in het nieuwe wetboek gaat het alleen om zaken waarin noch de verdachte, noch een raadsman ter verdediging aanwezig geweest is. Het Gerecht is tot een vonnis gekomen zonder enig weerwoord tegen de stellingen van de officier van justitie. Door de afschaffing van het verzet in misdrijfzaken vervliegt één van de twee feitelijke instanties. Dat zou wat ons betreft alleen geoorloofd zijn ingeval er expliciet afstand is gedaan van de instantie, dus van aanwezigheid bij de berechting in eerste aanleg. Enkel een geldige betekening en een afwezige verdachte lijkt ons daartoe onvoldoende basis te bieden, vanwege de vérstrekkende consequenties. Het is derhalve geboden dat de rechter in eerste aanleg de houding aanneemt dat de afdoening van een misdrijf bij verstek tot een absoluut minimum beperkt wordt. Helaas biedt het praktijkonderzoek onvoldoende aanknopingspunten voor een antwoord op de logische vraag, welk stagnerend effect daarvan uit zal gaan. Dezelfde ongewisheid geldt voor de noodzaak dat voor een herbeoordeling van alle misdrijfzaken, ook die bij verstek, altijd een hof-combinatie opgesteld zal moeten worden, terwijl misschien het bieden van de gelegenheid tot weerwoord en de herbeoordeling door de unusrechter in eerste aanleg tot berusting in het vonnis zal leiden. We kunnen met de beperkte data hierover niets hard maken.

\section{Afsluiting en conclusie}

In dit artikel hebben we gereageerd op de inmiddels aangenomen inkrimping van de reikwijdte van het rechtsmiddel verzet. Daarbij vormde het systematische verband met de regeling van de berechting in afwezigheid van de verdachte de aanzet om ook dat stuk procesrecht in de bespreking te betrekken. We hebben het bestaande en het toekomstige recht van verstek en verzet analytisch beschreven en er de rechtspraak over het aanwezigheidsrecht, afkomstig van het EHRM, naast gehouden. Dat leidde tot een kritische kanttekening ten aanzien van het bestaande Arubaanse recht. Het bekritiseerde deel, de onduidelijkheid over de positie van de tot verdediging gemachtigde raadsman, wordt verbeterd in de nieuwe tekst van de wet.

Onder het nieuwe wetboek zullen we dus het beeld te zien krijgen zoals weergegeven in tabel 1 . 
Tabel 1

\begin{tabular}{llll}
\hline & Categorie & Berechting & Rechtmiddel \\
\hline $\mathbf{I}$ & Overtreding & Op tegenspraak & Hoger beroep \\
$\mathbf{2}$ & Overtreding & Bij verstek & Verzet \\
$\mathbf{3}$ & Misdrijf & Op tegenspraak & Hoger beroep \\
$\mathbf{4}$ & Misdrijf & Bij verstek & Hoger beroep \\
\hline
\end{tabular}

Op basis van onze studie zijn er twee conclusies voor de toekomst van belang. In zaken die onder regel 2 vallen zal het beleid moeten veranderen en zal aan een ingesteld verzet gevolg gegeven moeten worden. Gebeurt dat niet, dan kan de veroordeelde door verzet in te stellen in dit soort zaken, die getalsmatig niet irrelevant zijn, bewerkstelligen dat het vonnis de facto zijn betekenis verliest. Voor zaken die onder regel 4 vallen concluderen wij, dat het aanwezigheidsrecht en het recht op twee feitelijke instanties een last legt op de rechter in eerste aanleg. Die zal alleen tot een verstekvonnis mogen komen wanneer ondubbelzinnig en uitdrukkelijk afstand van aanwezigheid gedaan is.

Ons schema toont niet de praktijksituatie dat in een zaak een cumulatie van een of meer misdrijven met een of meer overtredingen in de tenlastelegging opgenomen is. Voor die gevallen kwamen we al tot de conclusie dat de nieuw vastgestelde regeling haar doel, namelijk het reduceren van verwarring, zeer waarschijnlijk niet zal bereiken. De zaak zal immers moeten worden gesplitst ten gevolge van het divergente rechtsmiddelenregiem. Daarom zou enige leiding door de wetgever, bijvoorbeeld door een aanvulling van de instructies voor de rechter in hoger beroep in artikel $406 \mathrm{~Sv}$, wel wenselijk geweest zijn. Die hebben wij echter niet aangetroffen. 